Prethodno priopćenje UDK: 531.5(045) Bošković, R. J. doi: $10.21464 /$ fi41206 Primljeno 4. 11. 2019.

\author{
Zlatko Juras \\ Strožanačka 49, HR-21312 Podstrana \\ zlatkojuras1@gmail.com
}

\title{
Gravitacija u Boškovića
}

\begin{abstract}
Sažetak
U Teoriji prirodne filozofije Ruđera Boškovića, dinamika materije opisana je krivuljom sila, privlačnih ili odbojnih - ovisno o udaljenostima centara sila. Na velikim udaljenostima krivulja sila manifestira se slično Newtonovoj gravitaciji. Gravitacija je integrativna za vidljivi svemir, ali ne i za hipotetičko mnoštvo svemira za koje je moguće da paralelno postoje razdvojeni odbojnom silom, što je usporedivo sa suvremenim konceptom tamne energije. U konceptu kontinuiranih sila u diskontinuiranoj materiji, Faraday prepoznaje ideju o dinamičkom elektromagnetskom polju, koju je dovršio Maxwell, a kasnije Einstein predviđa postojanje gravitacijskih valova, nedavno i detektiranih (2015. - 2017., project LIGO). Valna priroda materije realnog prostor-vremena nalazi se u Boškovićevu modelu na maloj skali krivulje sila, a atomsko-korpuskularna dinamika klasične mehanike na velikoj skali.
\end{abstract}

\section{Ključne riječi}

Ruđer Josip Bošković, gravitacija, materija, prostor, vrijeme, točka, kontinuitet, relativnost, svemir

U Teoriji prirodne filozofije, ${ }^{1}$ Ruđer Bošković postavlja model pojavljivanja stvari prirode po točkama materije obdarenima silama što među njima djeluju. Sve su sile momenti jedne temeljne sile, čiji se odbojni ili privlačni karakter manifestira kao ovisnost o udaljenosti među nedjeljivim, neprotežnim i neprobojnim točkama materije. U prethodnom razdoblju, od kada su Newton i Leibniz neovisno otkrili infinitezimalni račun i zasnovali matematičku analizu, ${ }^{2}$ aktualno je bilo pitanje o tome kako shvatiti egzistenciju čvrste materije u kontinuiranom prostoru djeljivom do u beskonačnost - je li i materija kontinuirana i, ako je djeljiva, u kakvom su sklopu njezini elementi. Bošković sintetizira Newtonovo učenje o gravitaciji i drugim silama i Leibnizovo učenje o jednostavnim elementima, postupno gradeći sustav prirode u kojem

Theoria philosophiae naturalis prvi je put tiskana u Beču 1758., a u Veneciji 1763. Hrvatsko izdanje: Ruđer Bošković, Teorija prirodne filozofije, prev. Jakov Stipišić, redig. Žarko Dadić, Sveučilišna naklada Liber, Zagreb 1974. Ruđer Josip Bošković, isusovački teolog, filozof, astronom, fizičar, matematičar i geodet, rođen je u Dubrovniku 11. svibnja 1711., a preminuo 1787. Školovao se u Dubrovniku, a nakon Dubrovačkog isusovačkog kolegija u isusovačkom Rimskom kolegiju. Od 1735. studirao je Newtonovo učenje. Studij teologije započeo je 1738., istodobno s nastavničkim pozivom. Godine 1740 . vodi kolegij iz matematike na Rimskom kolegiju. Disertaciju De virbus vivis ( $O$ živim silama) objavio je 1745. a potom 1748 . godine De lumine ( $O$ svjetlosti), da bi sljedećih godina dovršio cjelovitu Teoriju, objavljenu 1758. u Beču.

\section{2}

Isaac Newton (1673. - 1727.) i Gottfried Leibniz (1646. - 1716.) istih su godina otkrili diferencijalno-integralni račun koji je omogućio matematički egzaktne izvode osnovnih zakona gibanja klasične mehanike, ali se ujedno postavilo pitanje o karakteru prostora i vremena u pogledu djeljivosti do u beskonačnost, što je bio uvjet za formu infinitezimalnog računa čiji limesi teže u nulu i beskonačnost. 
ideja sastavljivosti materije prethodi ideji djeljivosti prostora $\mathrm{k}$ realnom prostor-vremenu egzistencije prirode. ${ }^{3}$ Valno-čestična priroda materije prisutna je u Boškovićevoj zamisli o jedinstvenoj sili - jedinstvu privlačno-odbojnih sila. Stoljeće i pol nakon što je Bošković prezentirao svoju teoriju, nova će fizika otkrivati čestično-valnu prirodu elementarne materije.

Načelo jednostavnosti u prirodi navodi Boškovića na jednostavnost temeljnih čestica i jedinstvene sile, koja je kompleksna u našem poimanju, ali je u sebi jednostavna. ${ }^{4}$ Postavlja kvalitativni oblik dijagrama neprekidne krivulje što izražava sile, prikazujući na ordinati ubrzanja čestica. ${ }^{5}$ Krivulja je kontinuirana jer zakon kontinuiteta u prirodi ne dozvoljava skokovite promjene kvantitativnih veličina, sila koje kontinuirano djeluju u svim točkama imaginarnog prostora u koji su uronjeni realni prostor i vrijeme. ${ }^{6}$ Načelo kontinuiteta traži, smatra Bošković, kontinuirane mijene relativnih prostorno-vremenskih udaljenosti i relativnih brzina točaka materije. Newtonova gravitacija, čiji intenzitet opada proporcionalno kvadratu udaljenosti masivnih tijela, samo je jedan od članova jednadžbe Boškovićeve jedinstvene sile, a onaj od članova koji dominira u najmanjim udaljenostima treba biti takvog oblika, da brzo raste odbojna sila na graničnim udaljenostima točaka materije, što onemogućuje njihov dodir, omogućujući dalje složivost najmanjih elemenata prirode u veće strukture - agregate čestica višeg stupnja. Time se osigurava transparentnost i čvrstoća materije.

Za kvantitativne veličine i domene djelovanja raznih sila valja promatrati fenomene, njihove učinke, statističkim metodama utvrđivati njihova djelovanja te tako odrediti parametre koji u jednadžbi za ukupnost svih sila određuju domene pojedinih članova. Oni određuju njihovo pretezanje, opisujući pojedine dijelove krivulje za pojedine sile koje dominiraju odgovarajućim intervalima, udaljenostima među česticama. Upućuju i na složivosti raznih redova čestica u nultočkama krivulje, gdje odbojna sila prelazi u privlačnu - u točkama kohezije, za razne stupnjeve formiranja kompleksnije materije. Krivulja može imati mnogobrojne lukove i oscilatorna područja prije dominacije gravitacijskog luka. ${ }^{7}$ Po načelima analogije i sličnosti u prirodi može se kvalitativni oblik krivulje primijeniti i na područja nedostupna čulima i analogno razmatrati ustroj mikrosvemira i makrosvemira. Gravitacija je najočiglednija sila jer su njeni fenomeni dostupni motrenju i bez pomoći teleskopa, po motrenju gibanja vidljivih planeta, faza mjeseca, plime i oseke, ubrzanja u slobodnom padu i sl. Stoga je gravitacija polazno referentna za teoriju sila mikrosvijeta i makrosvijeta nedostupnih opažanju. U ono vrijeme, postavljalo se pitanje o stabilnosti materije u svemiru s obzirom na mogućnost općeg gravitiranja prema nekom centru svemirskih masa. Newton je sintetizirao nalaze Galileija o gravitacijskom ubrzanju na površini zemlje i tri Keplerova zakona eliptičnog gibanja nebeskih tijela te je izveo zakone klasične mehanike i formulirao zakon gravitacije. ${ }^{8}$

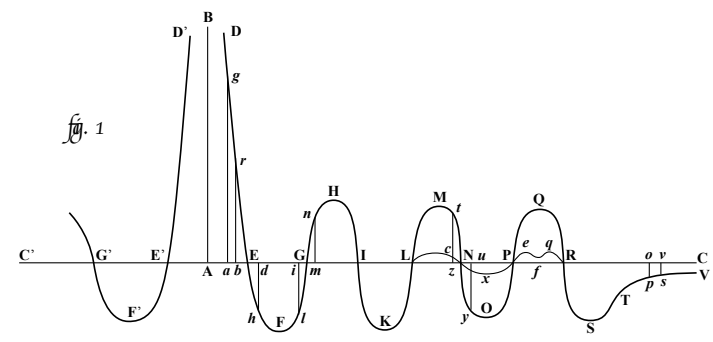


Slika 1: curva Boscovichiana prema: R. Bošković, »Dopune 1«, grafički suplement, tabela 1, fig. I., Teorija prirodne filozofije. ${ }^{9}$

Da gravitacija ne bi kolabirala materiju, Newton je zamislio beskonačan, homogen svemir u kojemu ne bi postojao istaknuti centar gravitiranja, nasuprot konceptu širećega ili stiskajućega totaliteta rastavljanja ili urušavanja materije. Slično, dosta kasnije (1917.), Albert Einstein nastojao je postići model stabilnog svemira, unoseći u jednadžbe opće teorije relativnosti tzv. kozmološku konstantu (energija vakuuma koja proizvodi ravnotežu s gravitacijskom energijom) za model statičkoga, homogenog i izotropnog svemira. ${ }^{10}$ To je bio neobičan koncept relativne ravnoteže energije prostora i materije u pro-

Kontinuirani prostor-vrijeme ispunjen je diskontinuiranom materijom čija je tvarnost karakterizirana dvostrukom prirodom točaka materije. Materijalne točke istodobno su građevne $\mathrm{i}$ izvori sila i kao takve pasivno produciraju realne čestice materije. Postojanje sila $\mathrm{u}$ prirodi stvaralačko je aktivno načelo kao uređaj više determinacije. Svijet ima početak u vremenu, a Boškovićev model tvorbe mogli bismo usporediti sa suvremenim modelima svemira. - R. Bošković, Teorija prirodne filozofije, str. 4-5; 191-198; 258.

4

U matematičkom dodatku Teorije, Bošković razmatra da »možda ima umova, različitih od naših ljudskih, koji tako duboko spoznaju neku drugu krivulju kao što mi ljudi spoznajemo pravac«. Ta bi krivulja mogla igrati ulogu koordinate u koordinatnom sustavu. Primjerice, takvim umovima bilo bi jednostavnije svesti pravac na krivulju nego obrnuto. $-\mathrm{R}$. Bošković, Teorija prirodne filozofije, str. 285. 5

Podrazumijeva pri tom da su materijalne točke jedinične mase, tako da je odbojna sila izražena ubrzanjima, postavljena pozitivnim, a privlačna negativnim vrijednostima na ordinati dijagrama, dok apscisa predstavlja međusobne razdaljine dviju točaka materije simetrično postavljene $\mathrm{u}$ pozitivnom i negativnom smjeru u odnosu na ishodište dijagrama sila. - Dubravko Tadić, »Građa tvari i Boškovićeve ideje«, u: Valentin Pozaić (ur.), Filozofija znanosti Ruđera Boškovića. Radovi simpozija Filozofsko-teološkog instituta DI, Filozofsko-teološki institut Družbe Isusove, Zagreb 1987., str. 103-128, ovdje str. 108; R. Bošković, Teorija prirodne filozofije, str. 285-287.

6

Imaginarni prostor-vrijeme je neki prostorno-vremenski vakuum u kojem materijalne točke imaju mogućnost postojanja u realnim točkama mjesta i trenutka kao u stvarnom prostoru i vremenu. Beskonačan, kontinuiran i djeljiv do $\mathrm{u}$ beskonačnost, vakuum u koji su tvarne točke materije uronjene nije neki prazan prostor, nego prostor koji ispunjavaju relacije međudje- lovanja sila koje iz njih izviru. - R. Bošković, Teorija prirodne filozofije, str. 170 , para. 372 ; »Dopune 1 - O prostoru i vremenu«, str. 265.

7

Doseg nuklearne sile je $10^{-15} \mathrm{~m}$. Još je manji doseg slabe sile $10^{-17} \mathrm{~m}$. Električna sila je za faktor $10^{38}$ jača od gravitacijske na atomskim udaljenostima, ali na udaljenostima većima od stotinke metra prevladava gravitacija.

8

U djelu Philosophiae naturalis principia mathematica, objavljenom 1687., Newton je formulirao zakone klasične mehanike. Galileo Galilej (1564. - 1642.) mjerio je Zemljino gravitacijsko ubrzanje $i$ formulirao načelo relativnosti za inercijalne sustave (načelo neovisnosti zakona fizike o izboru sustava mjerenja), bilo da se kreću jednolikim gibanjem, bilo da miruju. Johannes Kepler (1571. - 1630.) formulirao je tri zakona planetarne dinamike po promatranju gibanja eliptičnih putanja manjih tijela oko većih $u$ nekom od žarišta elipse. 9

Usp. Ivica Martinović, »Temeljna dedukcija Boškovićeve filozofije prirode«, u: V. Pozaić (ur.), Filozofija znanosti Ruđera Boškovića, str. $57-88$, ovdje str. 81 .

10

Stephen Weinberg, Prve tri minute ili Suvremeno viđenje porijekla svemira, prev. Anais Smailagić, Veselin Masleša, Sarajevo 1989., str. 36-38. Kozmološka konstanta (konstantni) član je Einstein uveo u svoje jednadžbe polja u cilju dobivanja statičkog kozmološkog modela svemira. Kasnije ga je napustio, ali on se još upotrebljava u složenijim modelima (kakav je Lemaitreov svemir). - Gerald E. Tauber, Einsteinova opća teorija relativnosti, prev. Damir Mikulčić, Globus, Zagreb 1984., str. 433.

11

Albert Einstein (1879. - 1955.) dobio je Nobelovu nagradu za fiziku za objašnjenje Brownova gibanja i fotoelektričnog efekta. Teoriju relativnosti objavio je 1916. Edmund Hubble 
stor-vremenu. Nakon E. Hubbleova otkrića širenja svemira (1929.), temeljem motrenja Dopplerovog pomaka ${ }^{11}$ spektralnih linija galaksija k crvenom dijelu spektra, bilo je očito da kozmološka konstanta nema značenje tadašnjih tumačenja širenja svemira. U to vrijeme nije se sagledavala uloga energije vakuuma ili, kako danas kažemo, tamne energije, za ubrzano širenje svemira, što bi bilo pravo značenje kozmološke konstante u Einsteinovim gravitacijskim jednadžbama postavljenima u neeuklidskom Riemannovu ${ }^{12}$ prostoru.

Ruđer Bošković problem stabilnosti materije razmatrao je, po oscilirajućem modelu privlačnih i odbojnih sila, u ravnoteži makroskale krajnjih udaljenosti i promjera svemirskih totaliteta koji su, ma kako veliki, ipak konačni i konačnog broja, ponašaju se isto kao i najmanje čestice i materijalne točke na mikroskali najmanjih udaljenosti, o čemu će biti riječi kasnije.

\section{Prostor polja sila}

Najveća svemirska tijela, isto kao i najmanji agregati materijalnih točaka i pojedine točke materije, kao da plove rasuti u vakuumu - u beskonačnom prostoru, ali ne istom kakvim ga je zamišljao Newton. Od njega je Bošković prihvatio formulaciju gravitacijske sile te ideju apsolutnog prostora kao imaginarnog prostora, u kojem su mogućnosti raznih izgleda oscilacija krivulje sila (slika 1) i time mogućnost raznovrsnih svemira različitih prirodnih zakona. ${ }^{13}$ Izrazom kao da točke materije plove rasute u vakuumu, Bošković sugerira da se gibaju u valovima polja sila - kontinuumom njihovih potencijala koji postavljaju potencijalne brzine, a djeluju diskontinuiranom čestičnom materijom što se giba aktualnim akcelerirajućim brzinama.

Kasnije se čini kao da i F. W. J. Schelling prosljeđuje Boškovićevo učenje o silama. Njegov je model odbojno-privlačnih sila, u ravnoteži polariteta u stvarima prirode, posve sličan Boškovićevu. Čestice materije su, u raznim stupnjevima-potencijama složivosti, relativni totaliteti što nastaju po polarnom postavljanju dvaju počela - teže i svjetla (primum existens - supstancija). Radi se o dvojstvu beskonačnih snaga apsolutnog identiteta. Snage ekspanzije i atrakcije, koje svojim produktom, u međusobnom kočenju, dokidanju dviju beskonačnosti, proizvode konačne stvari - čestice materije. Organizirana materija (secondum existens) ujedinjena je konačnim silama, odbojnim ili privlačnima, ovisno o prevagi realnog ili idealnog pola u stvarima. ${ }^{14}$ Momenti indiferencije polariteta $u$ Schellinga točke su relativne ravnoteže u čestičnim materijalnim cjelinama u sve kompleksnijim stupnjevima (potencijama) atomske i molekularne materije, analogno Boškovićevim točkama kohezije, dok je pretezanje pozitivnog ili negativnog pola u stvarima analogno pretezanju suprotnih sila oko točaka nekohezije. ${ }^{15}$

Točke materije stvarno, tj. realno postoje u lokalnim načinima mjesta i trenutaka koji nastaju i nestaju, a njihovim pomicanjem nastaje realni prostor-vrijeme. A kako je uzrok pomicanja točaka u silama među njima, sile oblikuju prostor-vrijeme, u čemu sagledavamo prisutnost Boškovićeva relativističkog poimanja stvarnosti, što kasnije prosljeđuje Einsteinova opća teorija relativnosti ili teorija gravitacije kao oblikovanja i zakrivljenja prostor-vremena od strane materije. Mjesta i trenutci koji nastaju i nestaju podsjećaju na virtualne čestice vakuuma, kvantne teorije polja, koje se pojavljuju i nestaju pri kretanju ili srazu elementarnih čestica. Kvantnoj je teoriji P. Dirac dao relativističko poopćenje, dok je R. Feynman ${ }^{16}$ poznatim dijagramima predstavio mehanizam interakcija u relativističkom obliku principa najmanjeg djelovanja, gdje 
čestica materije ima vlastito vrijeme. Promovirao je i partonsko-kvarkovsku fiziku. Kvarkovi se ponašaju analogno Boškovićevim točkama koje imaju vlastito mjesto i vrijeme (trenutak), a koegzistiraju u vremenu nakon samog početka stvaranja. ${ }^{17}$ Stoga, na moguće staze približavanja i udaljavanja dviju točka materije djeluju sve ostale točke materije u svemiru sa svim njihovim trenutnim potencijalnim brzinama (potencijali polja sila) ovisnima o međusobnim udaljenostima. Njima prethode sve kontinuirane promjene stvarnih udaljenosti od početka svemira, sve moguće povijesti - sve moguće staze materijalnih točaka - i svemira kao cjeline u imaginarnom prostor-vremenu, što je buduća ideja prisutna u Feynmanovim dijagramima.

Nema materije u apsolutnom mirovanju (kao ni apsolutne nule temperature) jer kada je materija jednom pokrenuta uvijek će se kretati, a ako su dvije točke

(1889. - 1953.), astronom koji je prvi pokazao širenje svemira, a po njemu je ime dobio prvi orbitalni teleskop. C. Doppler formulirao je 1842. promjene u valnoj dužini vala koji kreće od svoga izvora u kretanju iz perspektive motritelja. Dopplerov pomak spektralnih linija svjetla galaksija k crvenom dijelu spektra funkcionira na sljedeći način: one odašilju svjetlo krećući se relativnom brzinom $v$ spram motritelja, valna duljina svjetla $\mathrm{u}$ trenutku emisije je $L$, a u drugom je trenutku, kad stigne do motritelja, $L^{*}$ - omjer valnih duljina je $L^{*} /$ $\mathrm{L}=1 \pm \mathrm{v} / \mathrm{c} ;$ gdje $\mathrm{v}$ predstavlja relativnu brzinu parova galaksija $( \pm v)$ koje se relativno udaljuju $(+v)$ - crveni pomak spektralnih linija - ili približavaju $(-v)$ - plavi pomak, a c predstavlja brzinu svjetla.

12

B. Riemann (1826. - 1866.) poopćio je Gaussovu diferencijalnu geometriju s dvije dimenzije na n-dimenzija. Točka u n-dimenzionalnom prostoru opisana je $n * n$ tenzorom zakrivljenosti. Primjenjuje se na zakrivljenost prostor-vremena u općoj teoriji relativnosti.

13

Imaginarni prostor-vrijeme je neki prostorno-vremenski vakuum u kojem materijalne točke imaju mogućnost postojanja u realnim točkama mjesta i trenutka kao u stvarnom prostoru i vremenu. Beskonačan, kontinuiran i djeljiv do u beskonačnost, vakuum u koji su tvarne točke materije uronjene nije neki prazan prostor, nego prostor koji ispunjavaju relacije međudjelovanja sila koje iz njih izviru. - R. Bošković, Teorija prirodne filozofije, str. 170, 265.

14

F. W. J. Schelling (1775. - 1854.), usp. Zlatko Juras, »Vrijeme u Schellingovoj filozofiji prirode (O pojmu sile kod Boškovića i Schellinga)«, Filozofska istraživanja 21 (2001) 2-3, str. 291-324, ovdje str. 297.

15

U poglavlju »Dopuna $1-\mathrm{O}$ prostoru i vremenu«, može se sagledati entropijska narav materije jer je beskonačno nevjerojatno da se bilo koja točka materije bilo kada vrati u istu točku prostora (R. Bošković, Teorija prirodne filozofije, str. 269) - u analogiji sa Schellingovim modelom tvari - snaga indiferentnoga beskonačnoga bezdanskog prostora - teža, analogno Boškovićevim točkama sklonima ekspanziji i kohezionim momentima njegovo jedinstvene sile koja materiju drži na okupu konačnih totaliteta (snaga koja postavlja jedinstvo stvari - svjetlo - u Schellinga).

16

Za R. Feynmana (1918. - 1988.) T. Petković kaže: »... pravi interes je pokazivao Richard P. Feynman koji je Boškovićevu atomistiku prihvatio kao svoj filozofski credo 200 godina poslije [...] s preciznom partonsko-kvarkovskom fizikom u standardnome modelu.« - Tomislav Petković, Tomislav Petković ml., »Boškovićevo djelo u filozofiji prirode u razvoju moderne fizike čestica. O 300-toj obljetnici Boškovićevog rođenja «, Filozofska istraživanja 32 (2012) 2, str. 343-360, ovdje str. 343.

17

U početnim uvjetima ranog svemira točke materije imaju realne brzine, stvarne odnose prostornih udaljenosti, a odmah po početku stvaranja i vremenske udaljenosti. Iz zakona kontinuiteta slijedi da je stvarna udaljenost točaka materije osobina realnog relativističkog i relacijskog prostora-vremena koje u neprekinutim stazama točaka postoji od Početka. Kontinuirane mijene relativnih udaljenosti točaka materije u svakom momentu trenutno iskazuju potencijale sila koje determiniraju točke na udaljavanje ili približavanje (potencijalna brzina).

18

Boškovićeva analiza u »Dopuna 1 - O prostoru i vremenu«. 
materije na najvećim mogućim stvarnim udaljenostima gdje sustaje gravitacijsko privlačenje, ne mogu biti bez determiniranja na udaljavanje ili približavanje jer je to svojstvo samog temeljnog prostora. ${ }^{18}$ Zakon kontinuiteta ne dozvoljava skokovite promjene kvantitativnih veličina količine gibanja, što se ne može događati bez djelovanja sila. Da nema materije u mirovanju, pokazuje kvantna fizika Heisenbergovim relacijama neodređenosti ${ }^{19}$ - mirovanje kao neka određenost mjesta čestice izaziva neodređenost količine kretanja, što važi i za određenost trenutka spram neodređenosti energije čestice ili točke materije. ${ }^{20}$

Mogućnost kretanja točke materije u sljedeće mjesto i trenutak ostvaruje se djelovanjem sila (potencijalna brzina). Analogno tome, kvantna fizika postavlja umjesto pojma mogućnosti vjerojatnoću pojavljivanja ${ }^{21}$ u nekom prostornom stanju. Mogućnost ili vjerojatnost pojavljivanja čestice u nekoj točki prostora izazvana je superpozicijom svih privlačno-odbojnih sila svih točaka materije. Svaka točka materije zasebno je smještena u svom beskonačnom imaginarnom prostoru koji se preklapa s prostorima svih ostalih točaka. Svaka je izvor sila koje se zbrajaju, interferiraju međusobno u čitavom prostoru, postavljajući mogućnost, tj. vjerojatnoću dospijeća neke od njih upravo u tu točku prostora, što važi po analogiji i za trenutke - vremenske točke. Može se reći da je Bošković dao poticajne zamisli za razvoj klasičnih teorija fizikalnih polja sila, što su kasnije proslijedili M. Faraday i J. C. Maxwell, ${ }^{22}$ za elektromagnetsko polje u okvirima klasične mehanike, a poslije je uslijedio razvoj kvantne teorije polja začeto s M. Planckim, A. Einsteinom i N. Bohrom, koji je nakon J. Thomsonova modela atoma iz 1903. (inspiriranog Boškovićevim nalazom stabilnih - kvantnih - orbita u točkama kohezije), razvio kvantnomehanički model atoma. Valnu teoriju materije su, od klasične do relativističke formulacije dalje, razvijali E. Schrödinger, W. Heisenberg, P. Dirac, R. Feynman i drugi. ${ }^{23}$

\section{Gravitacija - toplinski model svemira}

Bošković smatra da je rub vidljivog svemira tako udaljen da proizvodi neznatan utjecaj:

»... neznatno gibanje koje odatle može proizaći u ono vrijeme o kojem smo mogli steći neko saznanje. Kada bi sve zvijezde stajačice ležale na istoj strani, to bi se gibanje moglo smatrati kao da ne postoji. $\ll^{24}$

Očito govori o našoj galaksiji - Mliječnom putu - koju vidimo s jedne strane noćnog neba. A ono vrijeme o kojem smo mogli steći neku spoznaju davno je prošlo vrijeme prije golemog niza vjekova. Time kaže da se ono što sada vidimo po svjetlu zvijezda događalo u ono vrijeme koje je trebalo svjetlu da dospije do nas, što vrijedi i za gravitacijski utjecaj koji treba isto to vrijeme da bi nastalo neznatno gibanje. Nakon golemog niza vjekova to nije moguće osjetilima zapaziti. Središte naše galaksije udaljeno je oko 26000 svjetlosnih godina - golemi niz od 260 vjekova - kako bi izrazio Bošković izjednačujući prostornu udaljenost s vremenskom udaljenošću, u skladu sa svojim relativističkim postavkama analogije prostora i vremena. Bio je u traganju za geometrijom koja bi predstavila četverodimenzionalni prostor-vrijeme i time realnije prikazala dinamiku materije. $\mathrm{Na}$ istom mjestu Bošković analizira ogromnost udaljenosti rubova vidljivog svemira i odgovarajući gravitacijski utjecaj, prema količini svjetla koje primamo od zvijezda: 
»Ako podrazumijevamo da su zvijezde stajačice jednake ili slične našem suncu, ili bar da omjer svjetlosti koje emitiraju ne odstupa mnogo od omjera masa, jer je i sila razmjerna tim masama, a osim toga kao sila tako i svjetlost opada obrnuto razmjerno kvadratu udaljenosti, onda će sila gravitacije našeg sunčanog sustava prema svim zvijezdama, u odnosu na silu naše gravitacije prema Suncu, koja je puno manja od sile gravitacije teških tijela oko nas prema Zemlji, stajati u

19

Werner Heisenberg (1901. - 1976.), dobitnik Nobelove nagrade za fiziku 1932. Matričkim jednadžbama prikazao je veličine klasične mehanike poput položaja i impulsa. Određenost tih veličina ne možemo istodobno sagledati zbog dvostruke valno-čestične prirode materije. Postoji minimalna veličina produkta Neodređenosti položaja čestice i neodređenosti impulsa - brzine u produktu $\mathrm{s}$ masom $(\Delta \mathrm{p} \Delta \mathrm{x} \geq \mathrm{h} / 2)$, te produkta neodređenosti energije i trajanja $(\Delta \mathrm{E} \Delta \mathrm{t} \geq \mathrm{h} / 2)$, a izražava ga reducirana Planckova konstanta $(\hbar=h / 2 \pi)$.

20

U Boškovićevoj teoriji impliciran je princip neodređenosti, kao i princip konačnosti broja točaka materije $\mathrm{u}$ realnom prostor-vremenu - konačne ekstenzije u neograničenom imaginarnom prostoru vakuuma. Načelo neodređenosti kvantne fizike izražava da mjerenje fizikalne pojave valne prirode locira istu pojavu kao česticu uz posljedicu neodređenosti njene brzine, $\mathrm{tj}$. posljedicu interakcije u mjerenju koja doprinosi energiji čestice. I obrnuto - mjerenje brzine izaziva neodređenost lokacije. Događanje opažanje čestice (primjerice osvjetljenjem) te određenost njenog položaja izaziva neodređenost impulsa - te ne možemo precizno odrediti stanje čestice opažanjem mjernim instrumentima. I Boškovićeva Teorija govori o tome da opažajni subjekt s instrumentima opažanja (npr. osvjetljenjem česticama svjetla) nije odvojen od objekta opažanja jer su naši instrumenti iste građe, podložni istim zakonima sila kao i objekt opažanja. Stoga su rezultati opažanja relativni s obzirom na interakciju subjekta opažanja i objekta. S druge strane - i s obzirom na relativnost pojavnog realnog prostora $\mathrm{i}$ vremena u odnosu na apsolutni prostor. Ova dvostruka relativnost rezultira izvjesnom neodređenošću te Bošković predlaže statistički pristup fenomenima, što će biti pristup i buduće kvantne fizike. O načelu neodređenosti u Boškovićevoj analizi sraza vidi više u: Z. Juras, »Vrijeme u Schellingovoj filozofiji prirode«, str. 299. O konačnosti svega što postoji Bošković piše sljedeće: »Ja nazivam obično cijeli niz mogućih nizom koji završava u konačnim granicama u beskonačnosti, jer sve ono što postoji mora biti ograničeno [...].«-R. Bošković, Teorija prirodne filozofije, str. 41.

21

Usp. Boris M. Yavorsky, Andrej A Detlaf, Handbook of Physics, Mir Publishers, Moskva
1975., str. 880; R. Bošković, »Dopune 1 - O prostoru i vremenu«, str. 170. Bošković analizira odnose mogućnosti i vjerojatnoće u relaciji imaginarni i realni prostor vrijeme. Realna metrika i vjerojatnost dinamike čestice - njenih, intenzivno ekstenzivnih veličina, pojavljuje se iz mnogostruke mogućnosti vakuuma. Traži omjere svih realnih kontinuiranih trajektorija točaka mjesta i točaka trenutaka $\mathrm{s}$ mogućim stazama $\mathrm{u}$ imaginarnom prostoru $\mathrm{s}$ time da beskonačna nevjerojatnost prelazi u neku relativnu nemogućnost.

22

M. Faraday (1782. - 1867.) zaslužan je za otkrića na području elektromagnetizma. Primijenio je Boškovićevu krivulju na fenomene kemijskih reakcija. J. C. Maxwell (1831. 1879.) matematički je formulirao Faradayeva otkrića te pokazao da je svjetlost elektromagnetski val. J. Thomson (1856. - 1940.) otkrio je 1897. elektron. Usavršio je Rutherfordov »planetarni« model atoma potpomognut Boškovićevom teorijom i njegovom oscilatornom silom koja razlikuje stabilne i nestabilne putanje orbitalnih čestica. Predstavio je atom kao harmonični oscilator: elektroni $u$ atomu osciliraju oko ravnotežnih položaja, a u preskocima emitiraju - apsorbiraju elektromagnetske valove.

23

Niels Bohr (1885. - 1962.) dobitnik je Nobelove nagrade za fiziku 1922. Unaprijedio je model atoma kvantizacijom dozvoljenih elektronskih putanja zbog valne prirode elektrona (princip korespondencije). E. Schrödinger (1887. - 1961.) dobio je 1933. Nobelovu nagradu za fiziku. Formulirao je valnu jednadžbu, prostorno-vremensko stanje sustava u spektru vjerojatnoća za razna stanja zbog valne prirode materije (val vjerojatnoće), kao kvantnomehanički analogon Newtonovoj jednadžbi klasične mehanike za silu u vremensko-prostornoj evoluciji. P. Dirac dobitnik je Nobelove nagrade za fiziku 1933. Stvorio je sintezu matrične mehanike i valne jednadžbe, predvidio postojanje pozitrona antičestice elektrona te postavio relativistički oblik valne jednadžbe.

24

R. Bošković, Teorija prirodne filozofije, str. 184.

25

Ibid. 
omjeru kao što stoji svjetlost koju emitiraju sve zvijezde prema svjetlosti koju emitira Sunce. A to je isti omjer kao omjer noći prema danu s obzirom na svjetlost. « ${ }^{25}$

Dalje postavlja hipoteze koje bi odgovarale modelu otvorenog, širećeg svemira jer iza ruba vidljivosti možda djeluje odbojna sila konačnog rasta koja opet prelazi u privlačnu na još većim udaljenostima (slika 2), ili na tim udaljenostima gravitacija opet lokalno raste (slika 3 ), pa čak i asimptotski povlačeći lokalne skupove zvijezda na drugu stranu nekih »rubova« svemira - što nas može podsjetiti na supermasivne crne rupe, tako da ne dolazi do kolapsa u nekom »Velikom stisku« materije. Asimptotski bi se rast gravitacije neutralizirao $\mathrm{s}$ asimptotskom odbojnom silom iza rubova vidljivog svemira, zbrajajući se u rezultanti konačne odbojne sile što zatvara vidljivi svemir.

Bošković ne prihvaća Newtonovu ideju apsolutnog vremena. ${ }^{26}$ Je li svemir otvoren ili zatvoren prostor ovisi o relaciji gustoće materije i energije koju sadrži spram energije koja ga stvara. Kohezivno djelovanje daje granice realnom prostoru, ali ne ograničava odvijanje prostora od Početka, nego mu postavlja lokalni izgled - geodetske linije kao prostorno-vremenske staze materijalnih točaka. Moment stvaranja daje supstancijalni moment vremenu koje nije puka sukcesivnost stanja kao u Newtona, nego je u vremenu postavljena forma prirodnih zakona i samo vrijeme kao početak svega - početni trenutak - jest ta forma u jedinstvu s prostorom. Stoga, u kaosu mogućih rasporeda točaka materije u svemiru Stvoritelj bira uređeno početno stanje i početni trenutak iz svih beskonačnih trenutaka čitave vječnosti, da bi mogao izabrati

»... upravo onaj individualni trenutak u kojem bi stvorio materiju i iz svih onih mogućih beskonačnih stanja, i to upravo iz najvišeg stupnja beskonačnosti izabrati ono individualno stanje koje obuhvaća jednu od onih krivulja što prolaze kroz sve točke zahvaćene zadanim redom i na njoj one udaljenosti, brzine i smjerove. $\ll^{27}$

Početak svega u vremenu mogao bi značiti ${ }^{28}$ početno stanje nekog maksimalnog reda koji karakterizira homogenost i izotropnost s obzirom na svaku točku materije u sveukupnoj tvari. Ukoliko su točke tetraedarski razmještene na najmanjim međusobnim udaljenostima u prvoj domeni krivulje sila, prvog odbojnog asimptotskog luka - slijedit će njihova ekspanzija. Širenje njihova totaliteta, do prvog kohezivnog intervala, može predstavljati odvajanje i aktualno djelovanje gravitacije kao zasebne sile. Stoga, Bošković u imaginarnom prostoru razrađuje model savršeno neproničnog tijela ${ }^{29}$ (čime počinje poglavlje »Primjena teorije na fiziku«), koje bi se u realnom prostoru u točkama kohezije manifestiralo česticama prvog reda te potom drugoga reda itd., prema sve kompleksnijoj materiji. On dijagramom rastavlja sile koje djeluju na najmanjim udaljenostima među točkama materije na odbojnu i privlačnu, tako da obje rastu do u beskonačnost približavanjem točaka, ali s bržim rastom odbojne sile, tako da razlika među površinama pod lukovima krivulje predstavlja konačnu dominaciju odbojne sile. Razlika površina ispod lukova između dvije točke materije predstavlja trenutnu kinetičku energiju sustava točaka. Zbog prevage odbojne sile, to je rastuća brzina (enegija) rastavljanja, međusobnog odbijanja točaka koje se ipak ne mogu potpuno rastaviti zbog privlačnih sila na većim udaljenostima. Bošković tako modelira prostor nekog neraskidivog »zastora« koji bi se sastojao od piramidalnih elemenata što čine mozaički niz stegnut između dvije beskonačne plohe - asimptotske privlačne sile i asimptotske odbojne sile. U vrhovima tetraedarskih piramida nalaze se materijalne točke, njihove su baze na strani privlačne beskonačne plohe, a vrhovi smjeraju k odbojnoj plohi. 
»Ako bismo dakle u jednoj ravnini imali neprekinuti niz istostraničnih trokuta koji imaju te udaljenosti za stranice, pa ako bismo u svakom kutu postavili bilo koji broj točaka na međusobnu udaljenost što je dosta manja od udaljenosti onih dviju asimptota ili pojedinih točaka, nastao bi nekakav neraskidiv zastor, koji bi se ipak mogao pregibati na svaku od dužina što čine stranice trokuta i bilo bi ga moguće smotati poput starih svitaka $[\ldots] . \ll^{30}$

Time Bošković konstruira poput svitka spiralnu strukturu dviju poput valjka smotanih ploha piramidalne strukture rasporeda materijalnih točaka kao ideju stegnutog homogenog prostora točaka, $\mathrm{s}$ jedne strane asimptotskom privlačnom silom, a s druge strane odbojnom. Kada se ova čvrsto stegnuta spirala otpusti, u razvijanju ili širenju oslobađa čestice materije prvog reda, koje po piramidalnoj strukturi podsjećaju na nukleone (tri kvarka - gluoni), drugog reda (atomske jezgre) itd. Suvremeni toplinski model pojavljivanja materije ranog svemira, u uvjetima ogromne gustoće, energije i temperature, govori o jedinstvenoj sili Početka (jedinstvo beskonačne odbojne i privlačne sile u Boškovića kao temelj razvijenog oblika krivulje sila). Materija je uslijed ogromnih temperatura (brzina točaka) bila u plazmatičnom obliku. Čestice koje predstavljaju sile - u suvremenoj terminologiji gravitoni, gluoni, fotoni i bozoni slabe sile - nisu se u uvjetima vrelog početka stvaranja međusobno razlikovale, kao ni čestice koje predstavljaju izgradnju i složivost materijalnih stvari, poput kvarkova građevnih čestica za nukleone. ${ }^{31}$ Kad danas govorimo o ranom svemiru i tvarnom početku ekvivalencije energije i materije, jedinstvene sile početka, prije odvajanja gravitacije, pa potom jake i elektroslabe sile, govorimo i o tvari Boškovićeva modela prirode, gdje gdje su materijalne točke istodobno građevne i izvorišta međudjelovanja sila, $u$ simetriji energije i materije.

Tako bi se u duhu Boškovićeva korištenja prispodoba njegov model sila predočio s čvrsto stegnutom poput svitka, homogenom oprugom koja se nakon puštanja raširi i na kraju širenja dalje transverzalno i longitudinalno vibrira. Sve točke materije u njoj osciliraju oko kohezivnih točaka osnovnom frekvencijom. Ako se opruga istegne tako da čestice promijene znatnije međusobne udaljenosti i pristignu u nove točke kohezije i dalje će vibrirati, ali nekom drugom frekvencijom. Ovo je upravo prispodoba za ovakvo početno stanje materije - homogeno i izotropno s obzirom na tetraedarske skupove materijalnih točaka. Povećanjem udaljenosti među točkama javljali bi se sljedeći kohezivni intervali, manifestirale ostale sile na udaljenostima njihovih pojedi-

26

Za njega vrijeme ima početak, trenutak stvaranja prvog uređenog stanja materije i buduću, a ne prethodnu vječnost, stoga njegove hipotetičke modele izgleda svemira možemo usporediti sa suvremenim modelima. - R. Bošković, Teorija prirodne filozofije, str. 258. 27

Ibid.

28

Uređeno početno stanje materije može se postaviti na mnogo načina, a svako bi predstavljalo poseban svemir s možda i drugačijim zakonima fizike. Moguće su razne vrste temeljnih čestica, drugačijih zakona prirode mnoštvo mogućih kombinacija tih zakona za mnoštvo različitih uređenja svemira. Usp. R. Bošković, Teorija prirodne filozofije, str. 243.
29

Ibid., str. 164 i d. Prethodno govori o gravitaciji i koheziji kao općim svojstvima materije, za razliku od posebnih svojstava koja proizlaze iz produkta sa silama nekohezije.

30

Ibid., str. 165-166.

31

D. Tadić, »Građa tvari i Boškovićeve ideje«, str. 127. Na temperaturi $10^{32}$ stupnjeva Kelvina $10^{-43}$ sekunde nakon Početka sve četiri sile bile su jednakog intenziteta - vladala je potpuna simetrija. Prva se odvaja iz termičke ravnoteže Početka gravitacijska sila, zatim $10^{-35}$ sekunde jaka - na temp. $10^{27}$ st. K (gluoni - šest vrsta kvarkova), potom elektroslaba koja se potom rastavlja $10^{-8}$ sekunde nakon početka na slabu i elektromagnetsku na temp. $10^{15}$ st. K. 
načnih domena djelovanja. Širenjem totaliteta krivulja, sila pristiže u razvijeni oscilatorni oblik privlačno-odbojnih lukova sila - od početnog stanja jedinstva odbojno-privlačnih sila u stegnutosti imaginarnog spiralnog prostora u najmanje udaljenosti točaka u početku vremena, što nastoje postići suvremene teorije kvantne gravitacije, naime, da su sve sile u jedinstvu prisutne u najmanjem elementu (kvantu) prostor-vremena.

Dominacija odbojnog luka, gdje su latentno prisutne sve privlačne sile, širi prvotni prostor. U daljem širenju totaliteta, početak prvoga kohezivnog intervala što predstavlja gravitaciju (oslobađanje hipotetskih gravitona) postao bi posljednji, asimptotski se bližeći apscisi krivulje u razvijenom (raširenom) obliku Svemira. Ako na najvećim udaljenostima dodiruje apscisu, iskazuje na tom mjestu moguće zadnje stanje nekohezije, početak djelovanja odbojne sile, što u razvijenom svemiru biva silom koja razdvaja galaktička jata.

Razlika površina iznad privlačnih i odbojnih lukova krivulje, dobivenih njenom integracijom, predstavlja promjenu kinetičke energije sustava od dvije točke koje se međusobno približavaju ili udaljavaju, odakle možemo dobiti promjenu njihove relativne brzine. Kako tvrdi Bošković, »njihova će razlika koja se dobiva oduzimanjem zbroja svih privlačnih, i obratno, predstavljati porast ili opadanje kvadrata brzine prema tome poklapa li se gibanje sa smjerom sile ili je ono suprotnog smjera «. ${ }^{32}$ Zakon o održanju energije sugerira da bi ukupnost površina ispod odbojnih lukova trebao biti jednak zbroju površina ispod - kako bi se ostvarilo načelo da je zbroj svih približavanja i udaljavanja točaka u svemiru jednake veličine. Ova simetrija daje uravnotežen svemir u ravnoteži odbojnih i privlačnih sila. Stoga bi nacrt krivulje sila i njen izgled na najvećim udaljenostima, gdje biva moguće da gravitaciju smjenjuje odbojna sila, trebao zadovoljiti ovaj uvjet zbrajanja površina ispod krivulje. Površina ispod gravitacijskog luka predstavlja relativnu ravnotežu sila atrakcije sa silama repulzije izraženima s površinama ispod asimptotskog odbojnog luka na najmanjim udaljenostima i s onom ispod odbojne sile koja djeluje na možda najvećim udaljenostima. Može se zanemariti onaj oscilatorni dio krivulje koji predstavlja atomsko molekularnu materiju jer je ona relativno stabilna u ravnoteži odgovarajućih sila mikroskale.

\section{Širenje svemira}

Po Boškovićevu mišljenju, ako bi gravitacijska sila postojala na najvećim udaljenostima, onda bi sva materija

»... napuštala ono stanje u kojem je sazdana i sva bi nužno srljala u propast, dok bi se cijela materija na kraju morala zbiti u jednu jedinu bezobličnu masu, jer uzajamnu gravitaciju zvijezda ne bi poništilo nikakvo koso ili krivocrtno gibanje. $\ll^{33}$

Nadalje, kaže da to nije lako dokazati, iako smatra da je duhovnija ona teorija koja otvara put izbjegavanju opće propasti prirode. A to otvara upravo njegova teorija, dopuštajući postojanje obuhvatnijeg svijeta od vidljivog svemira - prostora mnoštva svemirskih područja razdvojenih nekom odbojnom silom. Jer ako se i dopusti da, po Newtonovu zakonu, gravitacija opada s udaljenošću, moglo bi se pretpostaviti da

»... postoji neka druga sila prikazana nekom drugom, na koju se silu i gravitaciju, koja je potpuno recipročna kvadratima udaljenosti, može rastaviti zakon sila [...]. Ta bi sila na onim udaljenostima na kojima gravitacija, koliko god je moguće, slijedi taj zakon, bila neosjetna, da bi na drugim brojnim udaljenostima bila golema. $\ll^{34}$ 
Prevlast odbojne sile proizvodi ubrzano rastezanje, $\mathrm{tj}$. širenje prostora (slika 2). Oduzimanje ploha ispod krivulje sila između područja prevlasti te, nazovimo, makroodbojne sile i područja gdje prevladava gravitacija, daje razliku kvadrata brzine koje neko tijelo postiže krećući se u polju tih sila od jedne do druge udaljenosti. ${ }^{35}$

Dodatnom tezom o mogućnosti zasebnih svemira odvojenih asimptotskom odbojnom silom, on pojačava hipotezu o mogućem mnoštvu svemirskih područja razdvojenih nekom konačnom odbojnom silom. Oni pak pri tome koegzistiraju u obuhvatnijem univerzumu (slika 3), tako da nemaju nikakvog dodira.

Godine 2011. dodijeljena je Nobelova nagrada za fiziku ${ }^{36}$ za otkriće ubrzanog širenja svemira. Promatranjem sjaja udaljenih supernova, otkriveno je da se svemir širi pet do devet postotaka brže od predviđenog, s obzirom na proračune Hubbleova zakona širenja svemira, koji govori o o tome da je brzina međusobnog udaljavanja galaksija proporcionalna njihovoj udaljenosti. Prije otprilike devet milijardi godina svemir se počeo ubrzano širiti, za razliku od prethodećeg razdoblja postepenog usporavanja zbog dominacije gravitacije. U ovim domenama udaljenosti, gdje se po Dopplerovu efektu otkriva veći pomak spektralnih linija tipičnih galaksija k crvenom dijelu spektra od očekivanog, gravitacija, prevladana odbojnom silom energije vakuuma (što raste s rastom volumena širećeg svemira) ili, kako bismo danas rekli, tamne energije, nema više formativni karakter za totalitet vidljiva svemira, a integrativna je i dalje za lokalne cjeline galaktičkih jata.

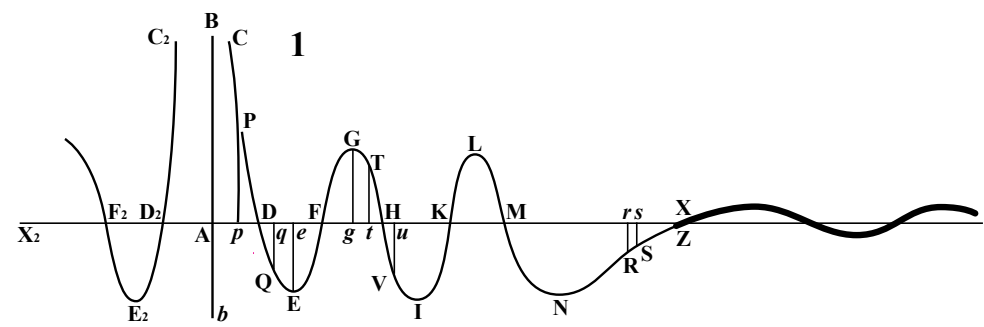

Slika 2: djelovanje sile na najvećim udaljenostima u području zvijezda stajačica. Rekonstrukcija prema De Lumine 2, 1748., n. 6; i De viribus vivis, 1745., n. 59. ${ }^{37}$

R. Bošković, Teorija prirodne filozofije, str 82. Ako je masa $(m)$ jedinična, izraz za silu $\mathrm{F}=$ ma može se pisati kao $\mathrm{F}=\mathrm{a}-$ sila njene vrijednosti na ordinati krivulje izražava se akceleracijom. Integracijom krivulje od točke $a$ do točke $b$ na apscisi $x$, tj. integracijom izra$\mathrm{za} a d x=(\mathrm{dv} / \mathrm{dt}) \mathrm{dx}=\mathrm{vdv}$, dobivamo kvadrat brzine proporcionalan kinetičkoj energiji koju točka postigne kretanjem u intervalu $a-b$.

33

Ibid., str. 185

34

Ibid., str. 182
35

Na velikim udaljenostima doprinos gravitacije je zanemariv spram golemosti, kako kaže Bošković, odbojne sile, te tako dobivamo između dva područja gdje gravitacija trne, prirast kvadrata brzine čestične materije - a što je u proporciji s prirastom kinetičke energije galaksija koje se relativno ubrzano udaljavaju. - Ibid.

36

Dobitnici su A. Reiss, S. Perlmutter i B. Schmidt.

37

Prema: I. Martinović, »Temeljna dedukcija Boškovićeve filozofije prirode«, str. 79. 
Pretpostavljajući postojanje odbojne sile na najvećim udaljenostima (slika 2), Bošković indirektno postavlja hipotezu ubrzanog širenja svemira na njegovim rubnim regijama. Razmatra mogućnost da se sva veća tijela, poput zvijezda, pa i čitav vidljivi svemir spram moguće postojećih susjednih svemira odnosi kao jedna jedina točka mikrosvijeta s obzirom na druge, čime anticipira neke od suvremenih teorija kozmičke inflacije koja rezultira množinom svemira:

$»$ Može se naime dogoditi [...] da onaj posljednji luk moje krivulje koji iskazuje gravitaciju, nakon što dosegne udaljenost koja je veća nego što je najveća udaljenost Sunca od svih kometa što pripadaju sunčanom sustavu, započne odstupati mnogo od hiperbole kojoj su ordinate obrnuto razmjerne kvadratima udaljenosti te da ponovno siječe os i ovije se oko nje. Na taj bi se način moglo dogoditi da skup zvijezda zajedno sa Suncem postane jedna jedina čestica reda koji je viši s obzirom na one koji sačinjavaju sam taj sustav i pripadne sustavu koji je još neizmjerno veći, pa bi moglo doći do toga da najveći broj redova čestica te vrste bude takav da čestice istog reda budu međusobno potpuno odvojene bez ikakva mogućeg odlaženja jedne čestice k drugoj preko brojnih lukova moje krivulje. $^{38}$

Dalje kaže da, po njegovoj teoriji, iščezava poteškoća koja proizlazi iz nužnog približavanja zvijezda stajačica, s obzirom na prigovore Newtonovoj teoriji. U Boškovićevo doba pojam vidljivog svemira nije išao dalje od naše galaksije, a danas bi mogli usporediti njegovu meditaciju o veličini svemira s galaktičkim jatima kao česticama još višeg reda, ali i čitavim vidljivim svemirom koji danas sagledavamo, a koji je promjera oko 93 milijarde svjetlosnih godina. Hipotetički, ako postoji više zasebnih, susjednih svemira, na udaljenostima onkraj granica našega vidljiva svemira, moguće je da se na makroskali udaljenosti ponašaju (po Boškoviću mišljenju) kao materijalne točke na najmanjim udaljenostima mikroskale, nemajući fizičkog dodira, razdvojene odbojnom silom. ${ }^{39}$

Stephen Hawking razmatrao je teorijske mogućnosti za koncepte usporednih svemira s obzirom na inflacijsku teoriju u sklopu toplinskog modela svemira - »velikog praska«.. Zadnjim objavljenim radom (2018. $)^{40}$ istražuje mogućnost koegzistencije konačnog broja svemira. Kozmička inflacija je moguće eksponencijalno uvećanje ranog svemira u malom djeliću vremena $10^{-35}-10^{-34} \mathrm{sec}$. nakon Početka. Inflacijsko polje širi prostor većom brzinom od brzine svjetla prvih momenata Velikog praska i uvećava prostor za $10^{25}$ puta. Teoriju je postavio Alan Guth 1979., pri čemu je objasnio izotropnost, homogenost i veoma mali stupanj zakrivljenosti prostora. Danas, na temelju pozadinskog zračenja zaostalog iz rane faze tvorbe, vidimo najranija događanja početka svega do prije 13,8 milijardi svjetlosnih godina. Vidljivi svemir se od tada proširio do dijametra od oko 93 milijarde svjetlosnih godina, a onaj nevidljivi dio koji okružuje vidljivi, ako je zatvorenog tipa, mogao bi imati više od dvije stotine puta veći promjer. Kvantna teorija nadaje mogućnost više inflacijskih područja tzv. kaotične vječne inflacije - zbog raznih mogućih stanja svemira u kvantnim fluktuacijama početnih stanja koja bi rezultirala s više svemira što mogu imati zasebne zakone fizike. ${ }^{41}$

\section{Tamna materija}

Postoji mogućnost da neka druga vrsta materije koegzistira u istom prostoru, ali drugačiji zakoni prirode možda onemogućuju međusobnu interakciju i zamjetljivost. Jedino bi gravitacija koja se prva odvojila kao zasebna sila prije inflacijskog eksponencijalnog širenja prostora osjećala prisustvo druge vrste 
materije. Nije poznato porijeklo tzv. tamne materije koja doprinosi energiji svemira u pogledu gravitacijske dinamike, a ne reagira na druge sile koje grade zamjetljivu nukleonsku materiju. Bošković bi rekao da je to materija neke tuđe vrste koja bi mogla nezamijećeno koegzistirati s našom. Na jednom mjestu Teorije govori:

»... bilo bi moguće da neke točke materije nemaju nikakve sile, te u tom slučaju jedna vrsta materije slobodno bi prošla kroz drugu vrstu ili bi druga vrsta materije imala takve zakone koji nemaju s prvom vrstom uzajamnog zakona sila - moguće da postoje, brojni materijalni i zapažljivi svjetovi u istom prostoru, tako među sobom odvojeni, da jedan ne bi imao nikakve veze s drugim niti bi jedan ikada mogao saznati za drugi. $\aleph^{42}$

Danas znamo da tamna materija doprinosi oko $23 \%$ energiji svemira, ${ }^{43}$ Sagledamo li ono što Bošković tvrdi o zapažljivim svjetovima koji u tvorbi materije nemaju nikakve veze, zbog nekompatibilnosti sila mikrosvijeta što tvore složenije strukture (nukleonsku i atomsku materiju), mogli bismo zaključiti da, kad govori o opažanju, govori o makrosvijetu, o gravitaciji kao općem svojstvu materije. Za razliku od drugih sila koje određuju posebna svojstva, po gravitaciji ${ }^{44}$ se indirektno zapaža postojanje tamne materije, bez koje se ne bi mogla objasniti dinamika galaksija i masivnost svemirske cjeline.

38

R. Bošković, Teorija prirodne filozofije, str. 185 .

39

S druge strane, Bošković kaže da na još većim udaljenostima krivulja sila ponovno prelazi u neku privlačnu silu ovijajući se oko apscise (osi dijagrama koja predstavlja udaljenosti), da ponovno siječe os $i$ ovije se oko nje, što sugerira da bi ova privlačna sila bila analogna gravitaciji, ali ne bi bila ista jer bi rasla $\mathrm{s}$ udaljenošću. Slika 2 pokazuje prijelaz makroodbojne sile u neku makroprivlačnu (između dva hipotetička svemira) - koja najprije raste pa opada s povećanjem udaljenosti na različit način od gravitacije koja opada s kvadratom udaljenosti. A tih oscilacija od odbojne u privlačnu silu na razmeđama svemira ili svemirskih područja može biti više, a ostvarivale bi dinamičku stabilnost makrosvijeta, poput one $\mathrm{u}$ harmoničkoga oscilatora $\mathrm{u}$ mikrosvijetu.

40

Stephen William Hawking (1942. - 2018.) i Thomas Hertog (1975. - ) - zadnji objavljeni $\mathrm{rad} \gg \mathrm{A}$ smooth exit from eternal inflation?«, Journal of High Energy Physics (2018) 4, čl. br. 147, doi: https://doi.org/10.1007/ jhep04(2018)147.

41

»Svemir u kojem obitavamo, u matematikom žargonu je 'mjere nula', jedan od beskonačno njih. Takva ideja mnoštva svemira (engl. 'multiverse') dobila je dodatni poticaj nakon otkrila velikog broja rješenja (posebice vakuuma) koje nude teorije struna - nešto što je
Susskind nazvao krajobrazom struna (engl. 'string landscape'). Tih vakuuma po zadnjim proračunima može biti $10^{500}$, a na svakom od njih može postojati drugačije populirani svemir (s različitim konstantama prirode). Jedan scenarij za takvo mnoštvo svemira ponudio je A. Linde u svojoj teoriji kaotične inflacije [...].« - Ivica Picek, »Moderna kozmologija - trijumf i izazov fizike«, Fizički odsjek, Prirodoslovno-matematički fakultet, Sveučilište u Zagrebu. Dostupno na: http://www. phy.pmf.unizg.hr/ picek/Picek_HAZU05.pdf (pristupljeno 2. 4. 2020.).

42

R. Bošković, Teorija prirodne filozofije, str. 244.

43

I. Picek, »Moderna kozmologija«, str. 26. Neutrini su čestice koje veoma slabo reagiraju $\mathrm{s}$ ostalom materijom pa predstavljaju mogući doprinos u sastavu tamne tvari.

»Ako naiđemo na neke prirodne pojave koje se ne mogu objasniti jednom jedinom vrstom materije, bit će moguće da u tim slučajevima pretpostavimo više vrsta točaka koje se ravnaju po brojnim različitim zakonima [...]. Ti bi se zakoni mogli izraziti nekim krivuljama koje bi imale nešto zajedničko, kao napr. asimptotski luk neproničnosti i luk gravitacije [...].«-R. Bošković, Teorija prirodne filozofije, str. 243. 


\section{Granice svemira}

Mogućnost različitih svjetova, odnosno svemira, sličnih ili različitih zakona prirode, Bošković razmatra i na drugi način: dijagramom (slika 3) shematski postavlja krivulju sila u niz sve većih prostornih skala u gradaciji zasebnih cjelina prirode. Pri tome, gravitacijski luk na najvećim udaljenostima, umjesto da se asimptotski bliži apscisi i siječe je (kao u prethodnom modelu), asimptotski raste k sljedećoj ordinati - gravitacija ne trne nego raste do takvih razmjera da zatvara taj dio svemira. S druge strane, odbojna asimptota ne dozvoljava prijelaz materije u obuhvatniji prostor.

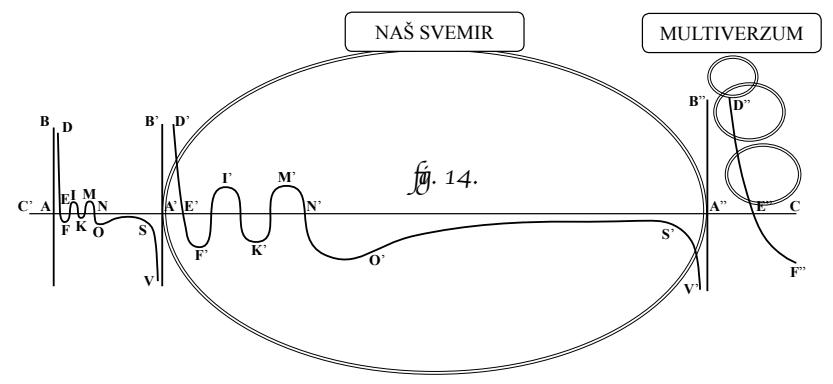

Slika 3: R. Bošković, »Dopune 1«, grafički suplement, tabela 1, fig. I4, Teorija prirodne filozofije. Slika dopunjena elipsama i odgovarajućim opisima. Elipse shematski označavaju razne svemire.

To nas upućuje na supermasivne crne rupe u središtima galaksija kao neke rubove, međaše našeg svemira. Bošković komentira mogućnost ovakvih pojava:

»... odatle se dade vrlo lako zaključiti da nema takva slučaja bar pri takvim udaljenostima koje se nalaze između promjera najmanjih čestica vidljivih mikroskopom i najvećih razmaka zvijezda koje gledamo teleskopom. Svjetlo naime vrlo slobodno prolazi kroz svaki takav razmak. Stoga, ako igdje postoje takve asimptotske granice, moraju postojati izvan sfere našeg zamjećivanja ili izvan svih zvijezda koje promatramo teleskopom ili unutar molekula koje promatramo mikroskopom. $\ll^{45}$

Danas su crne rupe zamjetljive po gravitacijskom utjecaju na okolne zvijezde i po zračenju ${ }^{46}$ koje se događa oko njihovih rubova. Bošković sluti da bi se po putanjama svjetla koje »slobodno« prolazi indirektno mogle zamijetiti pojave s ogromnim gravitacijskim silama na njihovom rubu. ${ }^{47}$

Kako zakon kontinuiteta zahtijeva neprekinutu krivulju sila, time zahtijeva i kontinuirani prijelaz asimptotske privlačne sile u asimptotsku odbojnu u imaginarnom prostor-vremenu, na način da ta ploha, s jedne strane odbojna, a s druge privlačna, poput neke sfere razdvaja obuhvatniji svijet-svemir od onog obuhvaćenog koji je poput točke s obzirom na prvi. Ta bi ploha trebala imati imaginarni prijelaz u beskonačnosti da bi pozitivna beskonačnost repulzivne sile imala kontinuirani prijelaz u negativnu beskonačnost atraktivne sile. Dvije komponente bi se u kontinuiranom prijelazu atrakcije u ekspanziju i obratno dokidale, kao suprotstavljene beskonačnosti u konačnom jedinstvu (kako kasnije i Schelling izvodi produkciju konačnih stvari) ${ }^{48}$ producirajući konačnu rezultantu odbojne sile obuhvatnijeg totaliteta, kako je već predstavljeno na slici 2, gdje se javlja oscilatorni dio krivulje koji razdvaja svjetove-svemire. Zaseban svijet može biti složena čestica ili neki veći nezavisan totalitet - pa i sam vidljivi svemir - a sadržan je u sljedećem totalitetu poput jedne točke: 
»... ako postavimo bilo koliko točaka između bilo koja dva para asimptota [...] pa ako ih pravilno poredamo, mogao bi, da tako kažem, nastati ma koliki broj svjetova, od kojih bi pojedini bili među sobom vrlo slični ili vrlo različiti, i to tako da nijedan od njih ne bi imao nikakve veze s drugim, jer nijedna točka ne bi mogla prodrijeti iz prostora koji je zatvoren s dva luka, s jedne strane odbojnim, s druge strane privlačnim. Dapače, svi bi svjetovi manjih dimenzija uzeti zajedno bili kao jedna jedina točka s obzirom na onaj veći, koji bi se s obzirom na sebe sastojao od vrlo sitnih točkastih masa $[\ldots]$. « $^{49}$

Različiti intervali među ordinatama predstavljaju razne skale udaljenosti za različite raspodjele energije-materije, tj. razne oblike prostora, $\mathrm{s}$ time da obuhvaćena sfera nije poremećena silama od one obuhvatne u smislu da bi se poremetila njena unutrašnja konfiguracija. Ako se obuhvatna sfera širi ili sažima, mijenja se polje sila u onoj obuhvaćenoj, ali na relativno simetričan, izotropan način, kao da na nju djeluje neki tlak prostora u koji je uronjena. Sile koje djeluju izotropno neutralizirale bi se utoliko ukoliko je oblik svijeta sferičan. ${ }^{50}$ Razlika površina ispod odbojnog i privlačnog asimptotskog luka (ili kinetičkih energija) rubnih dijelova intervala manjeg i većeg totaliteta, kao rezultantu daje dominaciju širenja prostora onog obuhvatnijega naspram onog manjeg, koji je u većem poput točke, kao i adekvatan omjer gustoće energije dvaju prostora (pretezanje tamne energije) spram čestične energije ili obrnuto, za razne stupnjeve prostornih cjelina.

Time Bošković za potrebe globalne ravnoteže univerzuma pretpostavlja mogućnost raznih stanja materije, raznih gustoća polja sila na različitim metričkim skalama (gradacijom sve većih svjetova na slici 3). Pri tome se stvaranje u Početku svega, od onog prije spomenutog početnog stanja »zida« od dvaju "zastora« beskonačnih sila odbojne i privlačne koje stežu početno stanje tvari točaka materije, može odvijati u više smjerova zbog raznovrsnih mogućnosti izgleda materije u početne tvari, uključujući i moguću materiju neke druge vrste (tamne vrste):

45

Ibid., str. 86.

46

Hawkingovo zračenje.

47

R. Bošković, Teorija prirodne filozofije, str. 79. Bošković analizira gradaciju dimenzija svjetova u svjetovima: »Svaki interval između ordinata na dijagramu (slika 3) predstavlja zaseban svijet jer je sa svoje strane odvojen od obuhvatnijeg svijeta barijerom asimptotske privlačne sile, a s druge strane barijerom odbojne.《

48

Z. Juras, »Vrijeme u Schellingovoj filozofiji prirode $\ll$, str. 298-298.

49

R. Bošković, Teorija prirodne filozofije, str. 78.

50

Međutim, po Boškovićevu mišljenju, nema potpuno euklidskih ploha i pravaca u prirodi - nema ravnih dužina i savršenih kugli, a time ni potpune neutralizacije vanjskih sila koje se osjete u unutrašnjosti prostora na koji djeluju unoseći time neku polarizaciju bez koje nema ni uređenog gibanja. Površine ispod odbojnih asimptotskih sila na dijagramu, koje izražavaju kinetičke energije, uvijek su veće od površina ispod privlačnih asimptota. - R. Bošković, Teorija prirodne filozofije, str. 170. Kako nema potpuno euklidskih ploha uvijek postoji neko mreškanje - fluktuacije na plohama koje razdvajaju 'svjetove'. Zgodna je sljedeća prispodoba kutije $u$ kutiji za fluktuacije - mreškanja plohe koja razdvaja prostore - onog obuhvatnog s onim kojeg obuhvaća: »... naš se pojam prostora povezuje s kutijom. No mogućnosti spremanja predmeta u kutiju, kako se pokazuje, sasvim su neovisne o debljini stijenke. Ne bismo li tu debljinu mogli smanjiti na nulu, bez gubitka »prostora «? Prirodnost postupka smanjivanja debljine stijenki kutije sasvim je očita, a sve što preostaje je prostor bez kutije.«- G. E. Tauber, Einsteinova opća teorija relativnosti, str. 385 .

51

Ibid., str. 167. 
»Ono što je pak predstavljeno zastorom ili zidom niza trokuta i piramida može se isto tako postići i drugim likovima, i to vrlo brojnim; a i to bi se moglo postići na više načina kada bi, ne na jednoj, nego na više udaljenosti, postojale takve asimptotičke pregrade koje bi dale za rezultat, kontinuiranu neproničnost, dok bi raspršene točke bile nekontinuirano raspoređene. $\ll^{51}$

Više praoblika ili vrsta veza među točkama materije (osim onog piramidalnog, tetraedarskog) može značiti više vrsta prirodnih zakona, uključujući i one koji omogućuju produkciju materije neke druge vrste i više područja stvaranja (na više udaljenosti takve asimptotičke pregrade).

To je aktualno i u suvremenoj inflacijskoj kozmologiji koja postavlja mogućnost više inflacijskih područja, pokušavajući povezati kvantne učinke gravitacije u okviru modela Velikog praska, tvarnog prapočetka svijeta, sa sadašnjim izgledom svemira. ${ }^{52}$ Singularitet kao apstraktna određenost postavio bi neodređenost energije početnog stanja svemira do u beskonačnost, a takva bi priroda bila kaotična. Ne bi bilo zakona prirode koji postavljaju uređen, stabilan svemir. Singularitet je točka beskonačne gustoće tvari i zakrivljenosti prostora i vremena, što je nerealna ideja. U Boškovića nema beskonačne gustoće materije jer ne postoji fizički dodir njenih točaka, a time nema ni singularnosti. Postoji pak ona najmanja udaljenost točaka materije i najkraće vrijeme, što predviđaju i relacije neodređenosti kvantne fizike - Planckova duljina i vrijeme..$^{53}$

Stephen Hawking, teoretičar kvantne gravitacije, navodi na koncept Feynmanovih dijagrama za čestice materije - da bi se možda mogao primijeniti na čitav svemir integracijom svih mogućih povijesti, od početnog stanja do danas, što navodi i Boškovićeva teorija, kako je naznačeno prije, jer prostor i vrijeme nastaju realizacijom mogućih staza za sve točke materije od početka vremena, a to je evolucija njihovih stvarnih prostorno-vremenskih udaljenosti. A koliko je parova točaka, toliko ima mogućih staza postavljenih zakonom sila te ih valja sve integrirati da bi se sagledala evolucija cjeline. Hawking razmatra

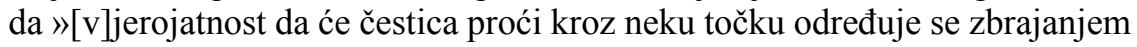
valova povezanih sa svakom mogućom povijesti koja prolazi kroz tu točku «, ${ }^{54}$ upućujući na Feynmana.

Mogli bismo Boškovićev dijagram na slici 3 interpretirati u usporedbi sa standardnim modelom svemira. Prvi »svijet« na dijagramu može predstaviti postinflacijsko razdoblje raznih stupnjeva dominacije energije nad čestičnom materijom ranog svemira, oslobađanja nuklearne sile i gradivnih kvarkova, sve do razdoblja formiranja atomske jezgre. Nukleon je građen od kvarkova, vezanim gluonima (jakim privlačnim silama što osiguravaju stabilnost nukleona), a kvarkove možemo prispodobiti Boškovićevim točkama. Nukleoni bi bili Boškovićeve čestice prvog reda, koje u najvećoj mjeri doprinose ukupnoj materiji svemira, a vrijeme njihovog života je daleko veće od starosti svemira. Sljedeći interval, tj. svijet, sadrži prethodne kao svoje točkaste elemente. U njemu bi točkasti svjetovi bili nukleoni i prve atomske jezgre, kao i ostale elementarne čestice i međudjelovanja oslobođenih sila. To bi bio čitav svemir nastao po dominaciji materije nad zračenjem, udruživanjem nukleona u jezgre (koje se s elektronima združuju u atom vodika itd.). Otprilike 380000 godina nakon Početka, svemir je postao transparentan za za zračenje. Pritisak je fotona prethodno onemogućavao združivanje elektrona s atomskim jezgrama. Danas to raspršeno zračenje vidimo kao pozadinsko zračenje na temperaturi od oko 2,7 stupnjeva Kelvina. Elektroni združeni s atomskim jezgrama u atome dalje formiraju kompleksniju materiju - od tada se svemir proširio za više od 1000 puta. Gravitacijski luk koji na kraju asimptotski raste može izražavati lokalnu formativnost galaksija, sve do stezanja materije u crnim rupama: 
u općem ubrzanom širenju svemira, ako se nastavi tako širiti, ostat će samo lokalne grupe galaksija u čijim su središtima supermasivne crne rupe. One će se međusobno približavati, poput bliženja susjedne Andromede našoj, pokazujući pomak spektralnih linija k plavom, tako da bi u dalekoj budućnosti formirale jednu galaksiju. Ako bi se globalni svemir nastavio ubrzano širiti, u nekoj bi budućnosti iz vidokruga nestala sva ostala galaktička jata jer bi se prostor rastezao većom brzinom od svjetlosti - reducirao bi se vidljivi svemir na obližnje galaksije koje nije rastavila tamna energija. Jata galaksija bila bi poput točaka zasebnih cjelina u trećem intervalu na dijagramu.

Sljedeći interval, tj. mogući svijet, predstavljao bi mogući multiverzum mnoštvo svemira nastalih sukcesijom inflacijskih momenata onda kada nastaje i naš svemir, u malom intervalu mikrovremena $\left(10^{-35}\right.$ sekunde) nakon Početka. Oni su u tom obuhvatnom prostoru u međusobnim relacijama kao jednostavne točke materije u našem svijetu. Prostor među njima širi se i dalje na način kako se širio prije inflacijskih momenata, a pojedini inflacijski mjehur-svemiri ponašali bi se kao da plove u njemu, kako bi rekao Bošković, dakle, poput mjehurića u vodi.

Širi li se svemir ili sažima uslijed gravitacije ovisi o tome ima li manju ili veću gustoću od granične, a što je ovisno o ukupnosti energije i mase u svemiru. Obična materija i energija te tamna materija skupa proizvode gravitacijsku atrakciju, dok tamna energija ima suprotni, antigravitacijski predznak. Boškovićev je svemir otvoren, širi se bar u prvoj oscilaciji krivulje nakon što trne gravitacija, a na još većoj skali udaljenosti oscilirajuća forma krivulje predstavlja model oscilirajućeg sustava različitih svemira. Time je Bošković, po načelima jednostavnosti i sličnosti u prirodi, analogno postavljao istu shemu sila na svim metričkim skalama, kako u vidljivom, tako i u nevidljivom području protežnosti materije, bilo u najmanjem mikrosvijetu, nedostupnom opažanjima, bilo u najvećim prostranstvima i totalitetima onkraj vidljivog svemira.

\section{Prostor teorije relativnosti}

Kao geometričar, služeći se uglavnom geometrijskom metodom za prikaz sila i gibanja, Bošković govori da je svaka geometrija idealna, ${ }^{55}$ da se formira prema raznim mogućnostima opažanja prostora i vremena. Neke krivulje bile bi referentnije od pravaca za zasnivanje opisa prostora i vremena jer ništa $u$

52

Kvantna teorija gravitacije otvara mogućnost početnog stanja bez singulariteta ili neke granice prostor-vremena. Usp. Stiven Hoking [Stephen Hawking], Kratka povest vremena, prev. Zoran Živković et al., Otokar Keršovani, Opatija 1988., str. 185.

53

»Planckovo vrijeme« $\left(10^{-43} \mathrm{sec}.\right)$ granica mjerljivosti trajanja odnosi se na vrijeme Početka Velikog praska pred odvajanje gravitacije iz termodinamičke ravnoteže početnog stanja, s dominantnim utjecajima kvantnih fluktuacija na budući izgled svemira u formiranju galaksija.
54

Stephen Hawking, Teorija svega. Podrijetlo i sudbina svemira, prev. Andrea Marić, V. B. Z., Zagreb 2009., str. 87.

55

R. Bošković, Teorija prirodne filozofije, str. 170.

56

Ibid., str. 52.

57

Po Boškovićevu mišljenju, prostor-vrijeme nastaje pomicanjem vlastitog mjesta-trenutka materijalnih točaka nekog tijela pod djelovanjem sila. - R. Bošković, Teorija prirodne filozofije, str. 267. 
prirodi nije pravocrtno. ${ }^{56}$ Zaista, zraka svjetlosti koja bi našim čulima bila najpogodnija u smislu pravocrtnosti prostiranja, za neki geometrijski opis prostora nije pravac, nego se, po Einsteinovoj općoj teoriji gravitacije, kreće zakrivljenom stazom oko masivnih objekata (po geodetskim linijama prostora), najkraćom stazom između dvaju mjesta u prostor-vremenu. ${ }^{57}$ Sile među tijelima oblikuju realni prostor i vrijeme. Između prostora je i vremena geometrijska analogija jer i prostor i vrijeme nastaju pomicanjem točaka materije i njihovih točaka 'mjesta' i 'trenutka' u kojima su smještene, uslijed kretanja uzrokovanog poljima sila među njima. $U$ analogiji prostora i vremena naslućuje se četverovektor koji opisuje događajne intervale u teoriji relativnosti. Bošković nalazi, kako je već prije rečeno, da su daleki svemirski objekti toliko udaljeni da proizvode neznatan utjecaj - »neznatno gibanje koje odatle može proizaći u ono vrijeme o kojem smo mogli steći neko saznanje [...] prije golemog niza vjekova «. ${ }^{58}$ Pri tome izjednačava brzinu svjetla i brzinu gravitacijskog utjecaja (čestice svjetla: fotona i hipotetičkog gravitona), a iz njegove teorije isto tako proizlazi da je vremenska udaljenost analogna prostornoj udaljenosti jer procjenjuje udaljenost nebeskih tijela brojem vjekova koje je svjetlo trebalo proći da bi pristiglo do motritelja. Tako Bošković na jednom mjestu razmatra doprinose svjetla gravitacijskoj energiji sustava $u$ kome se giba čestica svjetla:

»... zbog uzajamnih akcija miruje samo zajedničko središte kao imaginarna točka oko koje se gibaju sva tijela [...] zbog djelovanja jednog sustava na drugi, ma kako bio on udaljen, bit će preneseno na sama središta gravitacije stanovito gibanje. Ili još općenitije: dok se giba bilo koja čestica materije, npr. bilo koja čestica svjetla, sve ostale, ma kako bile udaljene, koje zbog toga mijenjaju svoj položaj prema njoj, mijenjaju i gravitaciju i zato se gibaju nekim gibanjem koje je neznatno, ali ipak takvo da priječi opće mirovanje. ( $^{59}$

Čestica svjetla ne giba se pravocrtno u gravitacijskom polju kojem i sama doprinosi svojom energijom. Iz stanovišta promatrača, sustav velike mase neće mijenjati svoj položaj spram roja čestica svjetla, nego će svaka na svoj način mijenjati smjer gibanja. ${ }^{60}$ Bošković kaže da će se, uzmemo li neku drvenu ili metalnu mjeru i prenosimo je prostorom, pri prenošenju uvijek nešto promijeniti:

»Moglo bi se dogoditi da podlegne nekoj znatnoj promjeni i ona i naša sjetila, promjeni koju mi ne bismo zapazili, i da se onda, pošto se vrati na prvašnje mjesto, vrati u stanje koje je jednako ili slično prvašnjem stanju. Međutim, u svakom slučaju ipak dolazi do neznatne promjene zato što sile koje povezuju međusobno one točke materije s obzirom na promjenu položaja prema svim točkama ostalih dijelova svijeta ipak doživljavaju neku promjenu. « ${ }^{61}$

Analogno važi i za vrijeme - ako se neki sat, neko trajanje prenosi drugome, da mjeri neko drugo trajanje, u prijenosu će dolaziti do promjene. Sat će subjektivno mjeriti jednako vrijeme jer će kazaljke prijeći jednaku udaljenost, ali to neće biti isto trajanje. Ovdje vidimo stavove buduće teorije relativnosti o dilataciji vremena i kontrakciji prostora u rastućom gravitacijskom polju. Pri tome je ekvivalentno kreće li se tijelo kroz razne potencijale gravitacijskog polja ili ono miruje u promjenljivom gravitacijskom polju, kao što je slučaj prolaza gravitacijskih valova kroz prostor koji pri tome trpi kontrakcije.

Godine 2017. dodijeljena je Nobelova nagrada za fiziku ${ }^{62}$ za opažanje gravitacijskih valova i doprinose na LIGO detektoru (laserski interferometar - opservatorij gravitacijskih valova), koji laserskim zrakama mjeri sitne promjene fizičkih objekata, desetak tisuća puta manjih od atomske jezgre. Nakon refleksije laserske zrake i mjerenja njenog spektra, utvrđuje se prostorna promjena, očitujući se u promjeni dužine krakova interferometra izazvanoj prolaskom gravitacijskog vala. 
Iz nesagledivosti početnog stanja stvorene materije i nedokučivosti onog reda prirode koji je Stvoritelj odabrao da bi mogao nastati život, kao i svjesno biće koje ga može spoznavati, a što se ne bi dogodilo da su zakoni prirode nešto drugačiji, kod Boškovića prepoznajemo antropsko načelo kozmologije. Iz iste nesagledivosti Početka nužno slijede relativistički nazori u pogledu odnosa pojavnog prostora egzistencije materije i apsolutnog prostora kao indiferentnog prostora puke mogućnosti za determinacijsku višnju silu koja bira upravo ovakve zakone prirode. To mu pomaže da neometano razvija svoje učenje kao pripadnik isusovačkog reda i time predstavnik Crkve. Kako je Crkva tek 1757. dopustila tiskanje knjiga koje naučavaju o gibanju Zemlje, Bošković u prethodnom razdoblju objavljuje pretpostavku (1746.) koja dozvoljava tu mogućnost.

Očigledan zakon gravitiranja manje masivnih tijela $\mathrm{k}$ onima masivnijima, a isti zakon se po svojoj prirodi suprotstavlja nepomičnosti Zemlje koja gravitira Suncu, Bošković postavlja u jedinstvo s tom mogućnošću, mada kao beskonačno nevjerojatnom, ali ipak mogućom i neprovjerljivom jer možemo motriti samo relativna gibanja između nebeskih tijela. On postavlja konstrukciju nepomičnosti Zemlje u apsolutnom prostoru, uz uvjet da se čitav vidljivi zvjezdani prostor koji je relativan, pokazujući samo relativna, a ne apsolutna gibanja, kreće u obrnutom smjeru od relativnog gibanja Zemlje spram njega. ${ }^{63}$

Za Boškovićevu geometriju pojavnog prostora realnije su neeuklidske geometrije te je zasnivanje opisa dinamike materije primjerenije po zakrivljenim nego po ravnim koordinatama. Kada uspoređuje jednostavnost pravca i neke od krivulja koje predstavljaju zakone sila kaže:

»Neki drugi način mišljenja koji bi jednako očito neko svojstvo bilo koje od njih (krivulja), kao što mi uočavamo kongruenciju pravaca, mogao bi te krivulje smatrati najjednostavnijima i iz toga njihova svojstva sačiniti sebi elemente neke posve druge geometrije i usporediti s njom ostale crte, kao što ih mi uspoređujemo s pravcem. $\ll^{64}$

Relativist Bošković govori da, ako se prostor širi ili sažima, mi ne bismo uočili nikakve promjene, jer svi fenomeni koje možemo mjeriti podliježu istom zakonu sila kao i naši opažajni instrumenti te ne sagledavamo apsolutne promjene nego samo relativne. ${ }^{65}$ Realne su relativne promjene prostor-

58

Ibid., str. 184.

59

Ibid., str. 39.

60

Ibid., str. 275. Za Boškovića, čestice se svjetla gibaju kao sve druge čestice materije, koje se u jakom gravitacijskom polju međusobno bliže, zauzimajući susjedne točke u prostoru. Zbog asimptotskih odbojnih sila javlja se disperzija smjerova gibanja. Dok gravitiraju masivnom tijelu, otklanjat će svoje gibanje od pravca što možemo sagledati efektom gravitacijske leće u blizini velike mase. Isto tako, bilo koje čvrsto tijelo mijenja svoju dužinu gibanjem kroz polja sila jer čestice od kojih se tijelo sastoji mijenjaju međusobne položaje mijenom sile.

61

Ibid., str. 274
62

Dobitnici su Rainer Weiss, Kip Thorne i Barry Barish. Godine 2015. prvi su puta opaženi gravitacijski valovi nastali kolizijom dviju crnih rupa. Do kolovoza 2017. bilo je još pet detekcija, a 17. 8. 2017. - sto godina nakon što je Einstein u općoj teoriji relativnosti predvidio postojanje gravitacijskih valova - detektirana je kolizija dviju neutronskih zvijezda koje su istodobno proizvele i svjetlosne signale.

63

Žarko Dadić, »Bošković i pitanje gibanja zemlje«, u: V. Pozaić (ur.), Filozofija znanosti Ruđera Boškovića, str. 129-135, ovdje str. 131.

64

R. Bošković, Teorija prirodne filozofije, str. 52.

65

Ibid., str. 274. 
no-vremenskih udaljenosti, relativne brzine i njihove promjene, što su kasniji stavovi Einsteinove specijalne i opće teorije relativnosti. Danas znamo da širenje realnog prostora možemo motriti i po promjeni $\mathrm{k}$ većim valnim duljinama svjetlosnih valova, ali ni to ne bi spadalo u apsolutne promjene jer naš vid ima svoje granice - granice vidljivog svemira koji je obuhvaćen većim svemirskim totalitetom za čiju dinamiku još uvijek postavljamo hipoteze.

\title{
Zlatko Juras
}

\section{Boscovich's Gravitation}

\begin{abstract}
In Roger Boscovich's Theory of Natural Philosophy, the dynamics of matter is described by the curve of forces, either attractive or repulsive - depending on the distances of the centres of forces. At great distances, the curve of forces is manifested similar to Newton's gravitation. The gravitation is integrative for the visible universe, but not for the hypothetical multitude of universes that possibly parallelly exist separated by a repulsive force, comparable to the contemporary concept of the dark energy. In the concept of continuous forces in a discontinuous matter, Faraday recognises the idea of a dynamic electromagnetic field, completed by Maxwell, while Einstein later predicted the existence of gravitational waves recently detected (2015 2017, LIGO project). The wave-nature of real space-time matter is found in Boscovich's model at the small scale of the curve of forces, while the atomic-corpuscular dynamics of classical mechanics is found at the large scale.
\end{abstract}

\section{Keywords}

Roger Joseph Boscovich, gravitation, matter, space, time, dot, continuum, relativity, universe 